\title{
The Influence of Parental Divorce on Depression Symptoms in Adolescence and Early Adulthood: A Systematic Review and Meta-Analysis
}

\author{
Haiwei Liu \\ The Dietrich School of Arts \&Sciences, University of Pittsburgh , Pittsburgh, Pennsylvania, USA, 15260 \\ hal162@pitt.edu
}

\begin{abstract}
Parental divorce, as one of the adverse childhood experiences, will have a negative influence on the mental health of adolescents. This study conducted a meta-analysis of depressive symptoms in children from parental divorce and adolescence and early adulthood. Through a series of meta-analysis to find the correlation between parental divorce and adolescent depression and tested the risk of publication bias. Two subgroup analyses are further studied and evaluated. A total of 9 studies in this trial were included in the meta-analysis $(\mathrm{N}=2089)$, and there was a significant correlation between parental divorce and children's depression $(\mathrm{SMD}=0.26,95 \% \mathrm{CI}=0.12,0.40)$. Adolescent women report more depressive symptoms than men. Based on the experimental results, this study speculates the factors that cause depression in adolescents and early adults due to parental divorce. Depression reports that rely on self-reports is restrictive. This finding supports the theory that parental divorce will produce negative depression for their children. Therefore, children with divorced parents should pay more attention to improving their mental health.
\end{abstract}

\section{Keywords: Meta-analysis, Parental Divorce, Depression, Mental Health, Adolescence, Early Adulthood}

\section{INTRODUCTION}

The impact of mental health on individuals, society and even the country is becoming more and more important recently [1]. People's childhood experiences will have an impact on the mental health of adolescents. Adverse childhood experiences can hinder people's ability to process emotions and cause people to experience depression and anxiety [3]. Parental divorce has arleady become one of the most common adverse child experiences [3]. Psychologists have investigated whether parental divorce will affect the mental health of their children for decades. Although some studies consider that parental divorce has little effect on the adolescent teenagers [4]. They believe that children's cognitive abilities are not negatively affected by their parents' divorce. Most of studies believe that parental divorce easily affects the mental health of young people.

Several previous studies have investigated the impact of parental divorce on children's mental health, but few studies have summarized and analyzed the impact of divorced families on teenagers' depression. In order to better understand whether young people really suffer from more depression due to parental divorce, this study seeks to conduct a systematic review and meta-analysis in previously published studies. Through the screening and data analysis of previous studies, it is verified whether adolescents and early adults whose parents are divorced have more depression than those whose parents are not divorced. Finally, this experiment also wants to explore whether factors will cause differences in the degree of depression among young people such as gender and country. The results of this experiment may have a more accurate discovery of the effects of parental divorce on adolescent depression, which will lay the foundation for future mental health of adolescents.

Previous studies have shown that the experience of early parental divorce can have a negative impact on children's psychology during adolescence and early adulthood [5]. For example, parental quarrels, reduction in family income, and unstable environments caused by moving may cause negative depression in adolescents [6]. According to Zill et al., children from divorced families are more easily to have a tense relationship with their father or mother [7]. These unstable factors make over $25 \%$ of young people whose parents divorced have received psychotherapy. Men from divorced families tend to have behavioral problems, while women more 
likely have emotional processing problems. The results of this study are not surprising because depression, as one of the most common mental disorders, is making hundreds of millions of people suffer in worldwide [2]. Especially adolescence is an important stage of human development, people at this stage are prone to have negative emotional disorders. WHO reports that depression is the second leading cause of suicide among people aged 15-29 [2]. Therefore, whether the bad experience of parental divorce will cause more depression in children has become a topic of interest to psychologists. This is also the reason why this research conducted a meta-analysis on this topic.

\section{METHOD}

\subsection{Search Strategies}

This experiment report refers to the PRISMA guidelines. The entire meta-study was retrieved independently by one reviewer, and the final retrieval was done until 13 July 2021. Researcher selected peerreviewed articles in the three main databases of PsychInfo, PUBMED, and EBSCOhost. Search keywords were as following (parental divorce OR parental separation) AND (depression OR mental health OR emotion). By looking at the title and abstract, researcher filters out articles that do not meet the criteria. Then the full text evaluation of the remaining articles is to confirm whether they meet the inclusion criteria. Finally, the references of qualified articles were checked to obtain relevant potential studies.

\subsection{Exclusion criteria}

The study exclusion criteria were as follows: All systematic reviews \& meta-analyses research; the topic is not about how parental divorce affects children; research with psychological intervention and drug control; experimental results report a mixture of depression and other psychological symptoms, such as anxiety and depression.

\subsection{Inclusion criteria}

The study inclusion criteria were as follows: research subjects must be human beings; studies must be published in English, and they are observational studies; participants were adolescent and early adult (15-29) people; participant's parents divorced before the participants were 18 years old; the control group is people whose parents are not divorced; the result is the participants' depressive symptoms.

\subsection{Data extraction}

All studies included in this meta-analysis have extracted data as following: author, country, year of publication, study design, sample size, age and gender of the participants, and depression measurement. The researcher selected data that can clearly measure the depression symptom scale, such as The Symptom Checklist, SCL-90. The mean and standard deviation of depressive symptoms were extracted according to the gender and age groups in those nine articles.

\subsection{Statistical Analysis}

This study uses the statistical method of metaanalysis to analyze the data. Data were put into a table in Microsoft Excel 2020 for Mac and analyzed by Stata/IC 16.0 for Mac (64-bit Intel). The I2 statistic was calculated to evaluate the heterogeneity between trials. When the heterogeneity of the study is large $(\mathrm{I} 2<50 \%)$, the fixed effects model is used; when the heterogeneity is small (I2 $<50 \%$ ), the random effects model is used. Draw a forest graph including standardized mean difference (SMD), potential moderators, and $95 \%$ confidence interval. To examine the risk of publication bias, the researcher used egger test, funnel chart and sensitivity test to evaluate the data. This study will also conduct several sets of subgroup analysis based on the data extracted from the data.

\section{RESULT}

According to the search results of the three databases, a total of 1786 articles were retrieved in this research. 322 was deleted due to duplication. A researcher independently screened by browsing the titles and abstracts, and 1464 articles were excluded. The researchers screened out 92 studies that did not meet the criteria by reading the full text. However, no article was identified by browsing the references of the 9 selected articles. Therefore, nine articles were included in this meta-analysis study (Figure 1). 


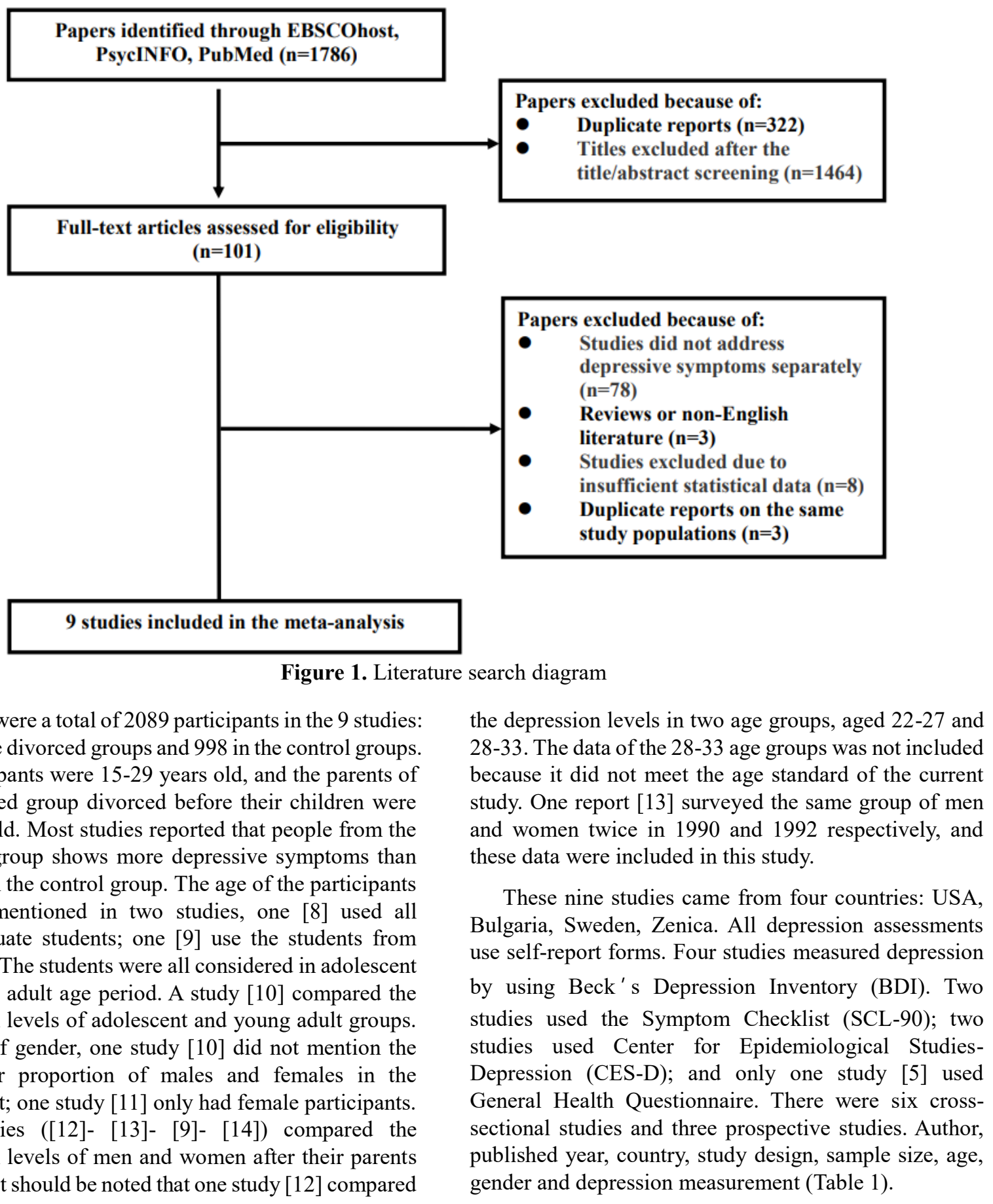

Table 1. A summary of studies included in the meta-analyses

\begin{tabular}{|c|c|c|c|c|c|c|}
\hline $\begin{array}{c}\text { Author } \\
\text { (Year) }\end{array}$ & $\begin{array}{c}\text { Countr } \\
\mathrm{y}\end{array}$ & $\begin{array}{c}\text { Research } \\
\text { Design }\end{array}$ & Sample Size & Sample Age & Gender & $\begin{array}{c}\text { Depression } \\
\text { Measurement }\end{array}$ \\
\hline $\begin{array}{c}\text { Ängarne- } \\
\text { Lindberg and } \\
\text { Wadsby } \\
\text { (2008) [12] }\end{array}$ & $\begin{array}{c}\text { Swede } \\
\mathrm{n}\end{array}$ & $\begin{array}{c}\text { Prospective } \\
\text { study }\end{array}$ & $\begin{array}{c}\text { Total: } 44 \\
\text { Divorced: } 22 \\
\text { Intact: } 22\end{array}$ & $22-27$ & $\begin{array}{c}\text { Female: } 22 \\
\text { Male: } 22\end{array}$ & $\begin{array}{c}\text { The Symptom } \\
\text { Checklist, SCL-90 }\end{array}$ \\
\hline $\begin{array}{c}\text { Christopoulo } \\
\text { S }\end{array}$ & $\begin{array}{c}\text { Bulgari } \\
\text { (2009) [8] }\end{array}$ & $\begin{array}{c}\text { Cross- } \\
\text { sectional } \\
\text { study }\end{array}$ & $\begin{array}{c}\text { Total:100 } \\
\text { Divorced:50 } \\
\text { Intact:50 }\end{array}$ & $\begin{array}{c}\text { Undergraduate } \\
\text { students }\end{array}$ & N/A & $\begin{array}{c}\text { General Health } \\
\text { Questionnaire }\end{array}$ \\
\hline
\end{tabular}




\begin{tabular}{|c|c|c|c|c|c|c|}
\hline $\begin{array}{l}\text { Cooney and } \\
\text { Kurz } \\
\text { (1996) [13] }\end{array}$ & USA & $\begin{array}{l}\text { Cross- } \\
\text { sectional } \\
\text { study }\end{array}$ & $\begin{array}{c}\text { Wave 1: } \\
\text { Total: } 482 \\
\text { Divorced: } 258 \\
\text { Intact: } 226 \\
\text { Wave 2: } \\
\text { Total: } 412 \\
\text { Divorced: } 213 \\
\text { Intact: } 199\end{array}$ & $18-23$ & $\begin{array}{l}\text { Wave 1: } \\
\text { Female: } 219 \\
\text { Male: } 263 \\
\text { Wave 2: } \\
\text { Female: } 180 \\
\text { Male: } 232\end{array}$ & $\begin{array}{c}\text { Center for } \\
\text { Epidemiological } \\
\text { Studies-Depression, } \\
\text { CES-D }\end{array}$ \\
\hline $\begin{array}{l}\text { Hadžikapeta } \\
\text { nović et al. } \\
\text { (2006) [15] }\end{array}$ & Zenica & $\begin{array}{l}\text { Prospective } \\
\text { study }\end{array}$ & $\begin{array}{c}\text { Total: } 249 \\
\text { Divorced:168 } \\
\text { Intact: } 81\end{array}$ & $\begin{array}{c}15-23 \\
\text { (Mean: 18.4) }\end{array}$ & $\begin{array}{l}\text { Female: } 162 \\
\text { Male: } 87\end{array}$ & $\begin{array}{c}\text { Beck's Depression } \\
\text { Inventory, BDI }\end{array}$ \\
\hline $\begin{array}{l}\text { Kerr and } \\
\text { Beer } \\
\text { (1992) [9] }\end{array}$ & USA & $\begin{array}{l}\text { Cross- } \\
\text { sectional } \\
\text { study }\end{array}$ & $\begin{array}{c}\text { Total: } 122 \\
\text { Divorced: } 22 \\
\text { Intact:100 }\end{array}$ & Grade 5-8 & $\begin{array}{l}\text { Female: } 55 \\
\text { Male: } 67\end{array}$ & $\begin{array}{l}\text { Beck Depression } \\
\text { Inventory, } \mathrm{BDI}\end{array}$ \\
\hline $\begin{array}{l}\text { McCabe } \\
\text { (2008) [10] }\end{array}$ & USA & $\begin{array}{l}\text { Cross- } \\
\text { sectional } \\
\text { study }\end{array}$ & $\begin{array}{c}\text { Total: } 71 \\
\text { Divorced: } 38 \\
\text { Intact: } 33\end{array}$ & $\begin{array}{c}\text { 18-22 } \\
\text { (Mean: 18.9) }\end{array}$ & $\begin{array}{l}\text { Female: } 38 \\
\text { Males: } 33\end{array}$ & $\begin{array}{l}\text { Beck Depression } \\
\text { Inventory, } \mathrm{BDI}\end{array}$ \\
\hline $\begin{array}{l}\text { Shifren et al. } \\
\text { (2015) [11] }\end{array}$ & USA & $\begin{array}{l}\text { Cross- } \\
\text { sectional } \\
\text { study }\end{array}$ & $\begin{array}{l}\text { Total: } 320 \\
\text { Divorced: } 194 \\
\text { Intact: } 126\end{array}$ & $\begin{array}{c}\text { 18-29 } \\
\text { (Divorced Mean: } \\
19.42 \\
\text { Intact Mean: 18.8) }\end{array}$ & $\begin{array}{l}\text { Female: } 320 \\
\text { Males: } 0\end{array}$ & $\begin{array}{c}\text { Center for } \\
\text { Epidemiological } \\
\text { Studies-Depression, } \\
\text { CES-D }\end{array}$ \\
\hline $\begin{array}{l}\text { Summers et } \\
\text { al. } \\
\text { (1998) [10] }\end{array}$ & USA & $\begin{array}{l}\text { Prospective } \\
\text { study }\end{array}$ & $\begin{array}{c}\text { Early } \\
\text { adolescence: } \\
\text { Total: } 285 \\
\text { Divorced: } 135 \\
\text { Intact: } 150 \\
\text { Early adult: } \\
\text { Total: } 242 \\
\text { Divorce: } 119 \\
\text { Intact: } 123\end{array}$ & $\begin{array}{l}\text { Early adolescence: 11- } \\
\qquad 15 \\
\text { Early adult: 18-22 }\end{array}$ & $\begin{array}{c}\text { Early } \\
\text { adolescence: } \\
\text { Female: } 142 \\
\text { Males: } 143 \\
\text { Early adult: } \\
\text { Female: } 125 \\
\text { Males: } 117\end{array}$ & $\begin{array}{l}\text { Beck Depression } \\
\text { Inventory, } \mathrm{BDI}\end{array}$ \\
\hline $\begin{array}{c}\text { Short } \\
\text { (2002) [16] }\end{array}$ & USA & $\begin{array}{l}\text { Cross- } \\
\text { sectional } \\
\text { study }\end{array}$ & $\begin{array}{c}\text { Total: } 174 \\
\text { Divorced: } 87 \\
\text { Intact: } 87\end{array}$ & $18-28$ & $\begin{array}{l}\text { Divorce: } \\
\text { Female: } 51 \\
\text { Males: } 36 \\
\text { Intact: } \\
\text { Female: } 46 \\
\text { Male: } 41\end{array}$ & $\begin{array}{l}\text { Symptom Checklist, } \\
\text { SCL-90 }\end{array}$ \\
\hline
\end{tabular}

\subsection{Meta-Analyses}

This meta-analysis included a total of nine studies and 16 group analyses. A random-effects model was selected because the heterogeneity was significant among studies $(\mathrm{I} 2=60.1 \%, \mathrm{p}=0.001<0.01)$. Parental divorce is significantly related to children's depression symptoms during adolescence and early adulthood $(\mathrm{SMD}=0.26, \quad 95 \% \quad \mathrm{CI}=0.12, \quad 0.40) \quad$ (Figure 2). No publication bias was tested from Egger's test $(\mathrm{P}=0.173)$ and Figure shows the funnel graph is symmetrical (Figure $3 \& 4$ ). In addition, sensitivity test found that the Lower CI limit is larger than $0.00(95 \% \mathrm{CI}=0.09)$ can also prove that the study has no publication bias (Figure $5)$. 


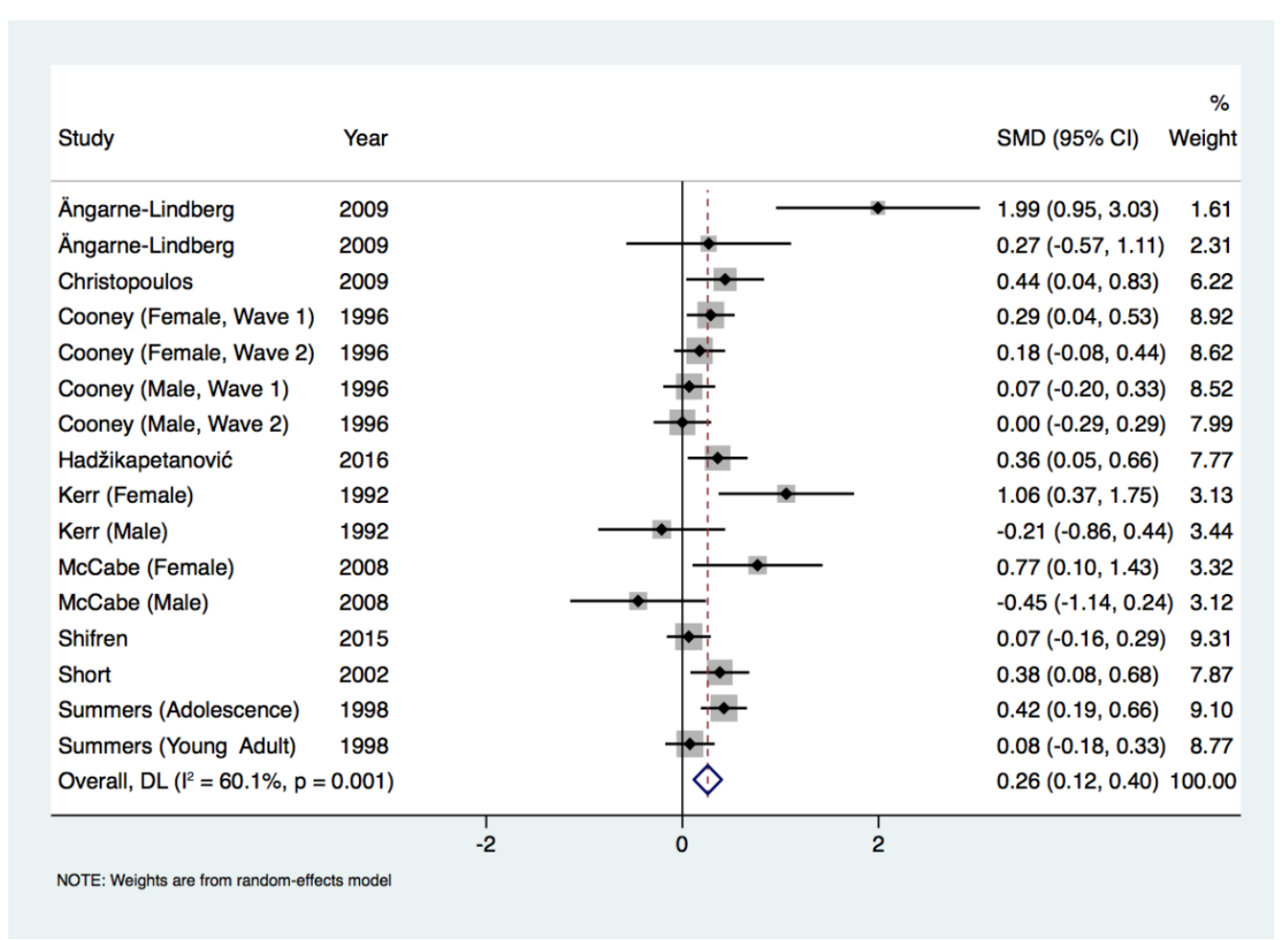

Figure 2. A forest plot of parental divorce on offspring depression

\begin{tabular}{|c|c|c|c|c|c|c|}
\hline \\
\hline \multicolumn{7}{|c|}{$\begin{array}{l}\text { Regress standard normal deviate of intervention } \\
\text { effect estimate against its standard error }\end{array}$} \\
\hline \multicolumn{5}{|c|}{ Number of studies $=\mathbf{1 6}$} & Root MSE & \\
\hline Std_Eff & Coef & Std. Err. & $\mathrm{t}$ & $P>|t|$ & [95\% Conf. & Interval] \\
\hline slope & .016453 & .1601104 & 0.10 & 0.920 & -.3269498 & .3598557 \\
\hline bias & 1.380905 & .962315 & 1.43 & 0.173 & -.6830551 & 3.444866 \\
\hline
\end{tabular}

Figure 3. Egger's test 


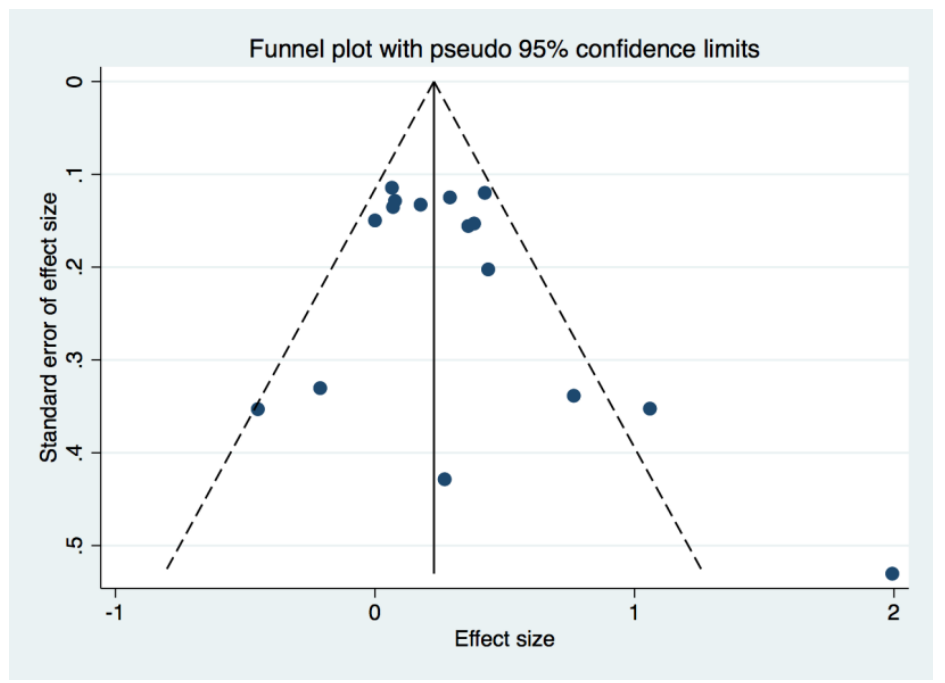

Figure 4. Funnel plot

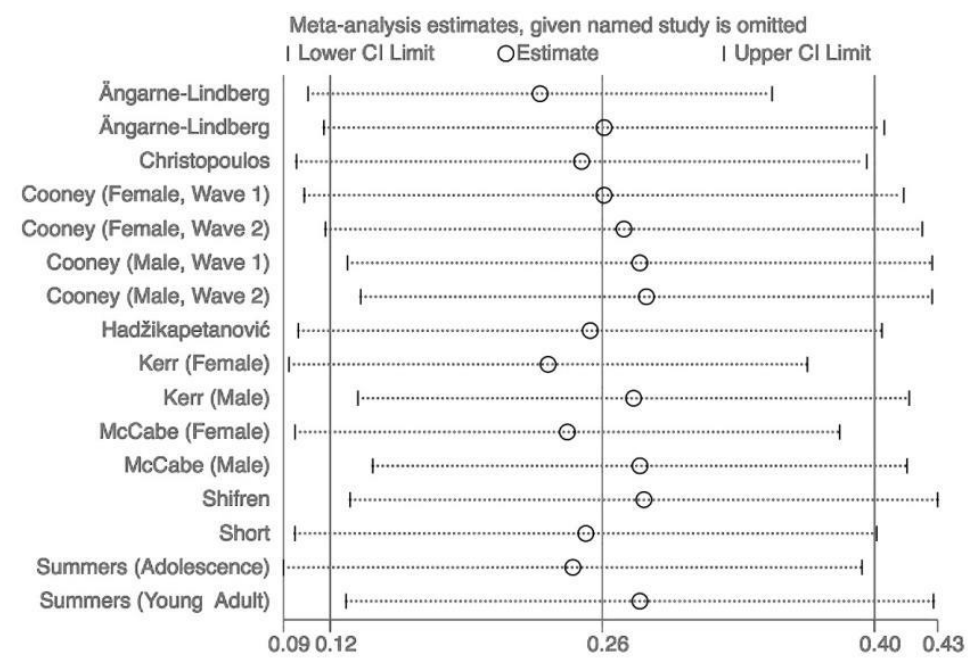

Figure 5. Sensitivity test

\subsection{Subgroup Analysis}

Two subgroups were analyzed according to gender of participants, countries of the studies (Figure 6\&7). Gender studies were divided into females, males, and mixed females and males (F\&M). Female participants in the divorced group still had more significant depression outcomes than women in the intact groups $(\mathrm{SMD}=0.48$, $95 \% \mathrm{CI}=0.16,0.81)$. Similarly, the mixed group also reported significant results $(\mathrm{SMD}=0.32,95 \% \mathrm{CI}=0.18$,
0.46). However, the results for men did not have heterogeneity $(\mathrm{I} 2=0.0 \%, \mathrm{p}=0.609>0.01)$. Men from the divorced groups did not have more depressive symptoms than men from the control groups $(\mathrm{SMD}=-0.00,95 \%$ $\mathrm{CI}=-0.18,-0.18)$. In addition, since the United States has the largest number of studies, the types of countries are divided into USA studies and non-U.S. studies. The statistical results show that the American group ( $\mathrm{SMD}=0.20,95 \% \mathrm{CI}=0.06,0.34$ ) has a smaller impact on depression of parental divorce than the non-American group $(\mathrm{SMD}=0.59,95 \% \mathrm{CI}=0.12,1.07)$. 


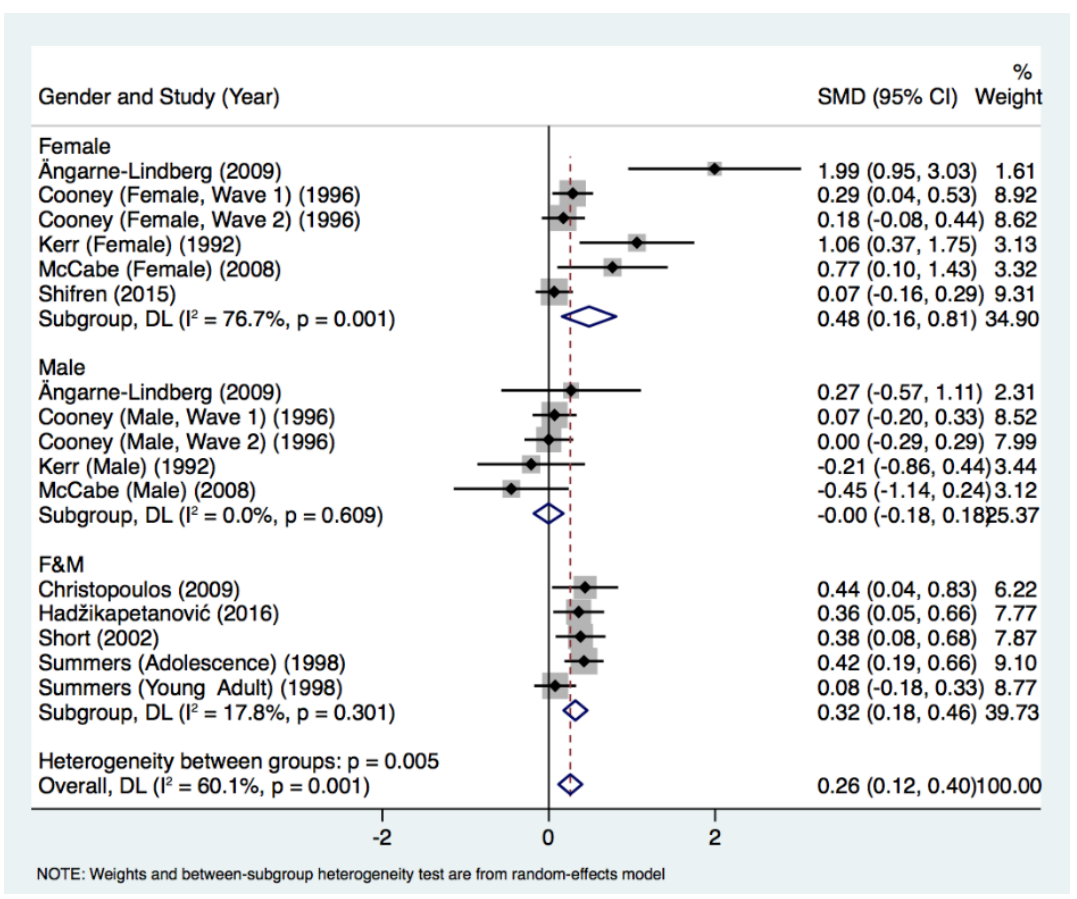

Figure 6. Subgroup analysis of gender

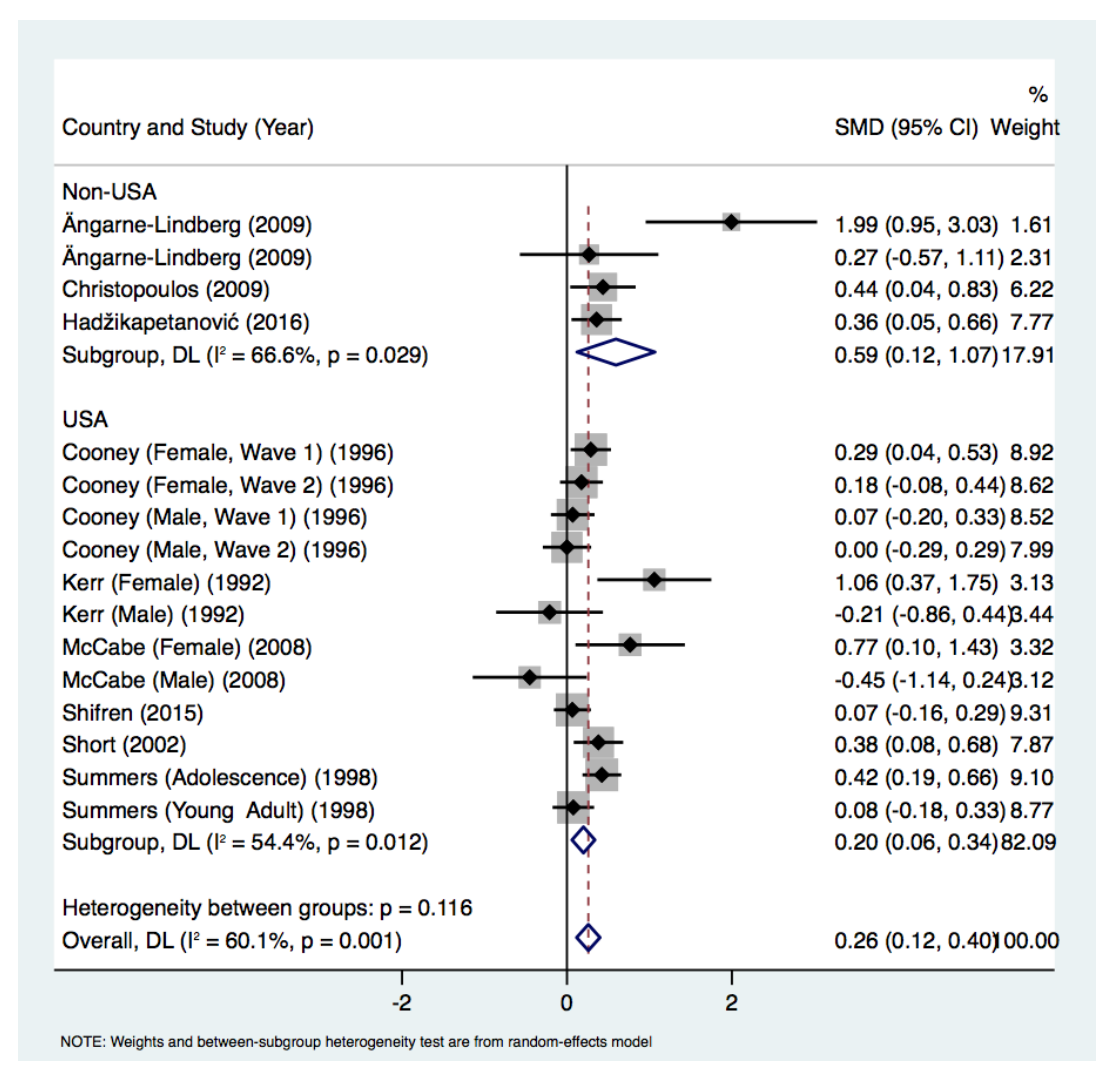

Figure 7. Subgroup analysis of country of studies

\section{DISCUSSION}

This meta-analysis shows that adolescent and young adults whose parents are divorced have more significant depressive symptoms than the parents who are still married. Subgroup analysis shows that women from divorced families have more depression levels than men. The reason for the negative emotions may be related to the problems arising from the divorce of the parents. For example, conflicts between parents after divorce can increase the risk of depression in children [17]. In addition, some studies have indicated that divorces of 
depressed parents are more common, so children of depressed parents are more likely to be depressed [18]. The family economic hardship after the parents divorced is also the cause of depression in adolescents [19]. Children who have experienced parental divorce in the early stage have a more negative attitude towards marriage than their parents have not divorce [20] and they may not know how to handle romantic relationships correctly. For people in adolescence and early adulthood, unstable emotions and interpersonal relationships can easily make them more negatively depressed.

\section{LIMITATION}

All reports on measuring depression in this research relied on self-reports, and the participants' subjective self-reports may generate response bias and affect the results of the experiment. In future research, researchers can use some professional clinical analysis to diagnose the child's depression. This experiment divided the country-related subgroup analysis into the USA group and the non-USA group. In fact, there are big differences between the three countries in non-USA. Because of the difference in cultural openness and economic development, parental divorce should have varying degrees of impact on children. This study cannot be studied deeper compared because there are only nine studies included in this research.

\section{CONCLUSION}

This study indicates that children who have experienced parental divorce during adolescence and early adulthood are more likely to suffer from depression. Women who have divorce parents showed more depression symptoms than men. Therefore, families and societies should provide more attention and help to teenagers from divorced families and strengthen selfawareness to prevent the risk of emotional disorders. Further research can consider whether the close relationship between parents and children will be a factor that affects emotional disorders. Research on more factors will help to develop mental health interventions for teenagers from divorced families.

\section{REFERENCES}

[1] World Health Organization. (2020). Depression. World Health

Organization. https://www.who.int/newsroom/fact-sheets/detail/depression

[2] Daines, C.L., Hansen, D., Novilla, M.L.B. et al. Effects of positive and negative childhood experiences on adult family health. BMC Public Health 21, 651 (2021) https://doi.org/10.1186/s12889-021-10732-w
[3] Sacks V, Murphey D. The prevalence of adverse childhood experiences, nationally, by estate, and by race or ethnicity. https://www.childtrends.org/publications/prevalenc e-adverse-childhood-experiences-nationally-staterace-ethnicity [accessed July 2019].

[4] Sanz-de-Galdeano, A., \& Vuri, D. (2007). Parental divorce and student's performance: Evidence from longitudinal data. Oxford Bulletin of Economics and Statistics, 69(3), 321-338. https://doi.org/10.1111/j.1468-0084.2006.00199.x

[5] Chase-Lansdale, P. L., \& Cherlin, A. J. (1995). The Long-Term Effects of Parental Divorce on the Mental Health of Young Adults: A Developmental Perspective. Child Development, 66(6), 1614 1634. https://doiorg.pitt.idm.oclc.org/10.2307/1131900

[6] Bohman, H., Låftman, S. B., Päären, A., \& Jonsson, U. (2017). Parental separation in childhood as a risk factor for depression in adulthood: a community-based study of adolescents screened for depression and followed up after 15 years. BMC psychiatry, 17(1), 117. https://doi.org/10.1186/s12888-017-1252-Z

[7] Zill, N., Morrison, D. R., \& Coiro, M. J. (1993). Long-term effects of parental divorce on parentchild relationships, adjustment, and achievement in young adulthood. Journal of Family Psychology, 7(1), 91-103. https://doi.org/10.1037/08933200.7.1.91

[8] Christopoulos, A. L. (2001). Relationships Between Parents' Marital Status and University Students' Mental Health, Views of Mothers and Views of Fathers: A Study in Bulgaria. Journal of Divorce \& Remarriage, 34(3/4), $179 . \quad$ https://doiorg.pitt.idm.oclc.org/10.1300/J087v34n03_11

[9] Kerr, J., \& Beer, J. (1992). Specific and diversive curiosity and depression in junior high school students of divorced and.. Psychological Reports, 71(1), 227. https://doi.org/10.2466/pr0.1992.71.1.227

[10] Summers, P., Forehand, R., Armistead, L., \& Tannenbaum, L. (1998). Parental divorce during early adolescence in Caucasian families: The role of family process. Journal of Consulting \& Clinical Psychology, 66(2), 327. https://doi.org/10.1037/0022-006X.66.2.327

[11] Shifren, K., Bauserman, R., Blackwood, J., Coles, A., \& Hillman, A. (2015). Personality and Mental Health: A Comparison of Emerging Adult Women from Divorce and Intact Families. Journal 
of Adult Development, 22(4), 221-229.

https://doi.org/10.1007/s10804-015-9213-6

[12] Ängarne-Lindberg, T., \& Wadsby, M. (2009). Fifteen years after parental divorce: mental health and experienced life-events. Nordic Journal of Psychiatry, 63(1), 32-43. https://doiorg.pitt.idm.oclc.org/10.1080/08039480802098386

[13] Cooney, T. M., \& Kurz, J. (1996). Mental health outcomes following recent parental divorce: The case of young adult offspring. Journal of Family Issues, 17(4),

495-513. http://dx.doi.org.pitt.idm.oclc.org/10.1177/019251 396017004004

[14] McCabe, K. M. (1997). Sex Differences in the Long Term Effects of Divorce on Children. Journal of Divorce \& Remarriage, 27(1/2), 123-135. https://doi.org/10.1300/J087v27n01_08

[15] Hadžikapetanović, H., Babić, T., \& Bjelošević, E. (2017). Depression and intimate relationships of adolescents from divorced families. Medicinski Glasnik, 14(1), 132-138. https://doiorg.pitt.idm.oclc.org/10.17392/854-16

[16] Short, J. L. (2003). The Effects of Parental Divorce During Childhood on College Students. Journal of Divorce \& Remarriage, 38(1/2), 143.

[17] O’Hara, K. L., Sandler, I. N., Wolchik, S. A., JennYun Tein, Rhodes, C. A., \& Tein, J.-Y. (2019). Parenting time, parenting quality, interparental conflict, and mental health problems of children in high-conflict divorce. Journal of Family Psychology, 33(6), 690- 703.

https://doi.org/10.1037/fam0000556

[18] Fendrich, M., Warner, V., \& Weissman, M. M. (1990). Family risk factors, parental depression, and psychopathology in offspring. Developmental Psychology, 26(1), 4050. https://doi.org/10.1037/0012-1649.26.1.40

[19] Strohschein, L. (2012). Parental Divorce and Child Mental Health: Accounting for Predisruption Differences. Journal of Divorce \& Remarriage, 53(6), 489-502. https://doi.org/10.1080/10502556.2012.682903

[20] Amato, P. R. (1988). Long-Term Implications of Parental Divorce for Adult Self-Concept. Journal of Family Issues, 9(2), 201-213. https://doi.org/10.1177/019251388009002003 